\title{
Government environmental regulation, corporate social responsibility, ecosystem innovation strategy and sustainable development of Vietnamese seafood enterprises
}

\author{
Thi Minh Nguyet Hoanga ${ }^{a}$, Thi Thai Thuy Nguyen ${ }^{\mathrm{b}}$ and Thi Thu Hien Phan $^{\mathrm{b}^{*}}$
}

${ }^{\mathrm{a}}$ Hanoi University of Natural Resources \& Environment, Vietnam

${ }^{b}$ University of Economics - Technology for Industries, Vietnam

CHRONI C L E

Article history:

Received: March 12, 2021

Received in revised format: June

20, 2021

Accepted: July 4, 2021

Available online: July 5, 2021

Keywords:

Government environmental regu-

lation

Corporate social responsibility

Enterprise sustainable business

growth

Vietnam

\section{Introduction}

Sustainable development is a fundamental concept in business management research through its association with a competitive advantage. Considerable progress has been made in this area in recent years, including moving away from the narrow definition of sustainability and competitive advantage based on superior economic performance over recognizing the importance of making connections with the economic, social and environmental impacts of business (Harrison et al., 2010). This has been argued from the perspective of corporate sustainability theory from stakeholders, where redefining the main purpose and objectives of the business is part of a system of influential stakeholders by corporate settings and goals (Freeman, 1984). The fisheries sector is an important economic sector in the Vietnamese economy. In the period 2010-2019, the gross domestic product (GDP) structure of the fisheries sector in the entire agricultural sector increased from $17.8 \%$ to $24.4 \%$. Fishery production increased from 5.1 million tons to 8.2 million tons. Seafood export turnover increased from 5 billion USD to 8.6 billion USD, equivalent to $1.7 \%$ of the total export value of the country and $20.8 \%$ of the export turnover of the agricultural sector. The industry has also built-up key commodities such as shrimp, pangasius, etc. Not only to meet the food supply, the presence of boats and fishermen on the seas has also played an important role in maintaining the stability, sovereignty and security of the country's seas and islands. Fishery creates jobs for about 3.9 million workers, contributing to restructuring the agricultural and rural economy. The material and spiritual life of the community participating in the development of fisheries has been increasingly improved. However, besides the above-mentioned achievements, the fisheries industry is still revealing many shortcomings and inadequacies, not commensurate with the potential and advantages of the country's fisheries development.

* Corresponding author. Tel.: +840914915926

E-mail address: ptthien.kt@uneti.edu.vn (T.T. H. Phan)

(C) 2021 by the authors; licensee Growing Science, Canada. doi: $10.5267 /$ j.ijdns.2021.7.010 
In recent years, the industry has faced a series of challenges from climate change, natural disasters, environment, product consumption market, etc. These are the impacts of historical drought and salinity occurring in Mekong Delta; marine environmental incidents in 4 central provinces, the European Commission withdrew the "yellow card" warning for fishery products caught. In 2020, drought, saltwater intrusion along with extreme weather, storms and floods will occur continuously in many localities; especially the COVID-19 pandemic has had a great impact not only on production and export but also on all aspects of life. In addition, establishments producing and trading shrimp and products containing impurities (including households involved in purchasing, preliminarily processing and putting impurities into raw shrimp) have a great influence on business reputation. Vietnamese seafood. Currently, seafood enterprises have not completely solved the shortcomings such as unstable workforce, managers, product responsibility, pressure to deal with the environment and still face many challenges such as lack of resources. customers, markets, lack of stakeholder needs in business cooperation, lack of supportive policies from the state and pressure of social issues in business. 2021 is also the first year for a new phase, the fisheries industry has set many new development orientations and goals; especially the implementation of the strategy to develop the fisheries sector to 2030 , with a vision to 2045 with many comprehensive and synchronous solutions in each field such as: protection and development of aquatic resources; fisheries logistics service establishments; aquaculture; fisheries; processing and trading seafood. Specifically, by 2030, the growth rate of aquaculture production value will reach from 3.0 to $4.0 \%$ /year; total domestic production of aquatic products 9.8 million tons; seafood export turnover reached 14-16 billion USD; all seafood production and trading establishments must ensure food safety and hygiene and environmental protection standards; creating jobs for more than 3.5 million fishery workers, with per capita income equivalent to the average income of the whole country. With a longer vision, the goal to 2045 is to develop fisheries into a modern, sustainable economic and trade industry with advanced management, science and technology, and an important position in the economic structure of the agricultural and marine economic sectors. Thus, sustainable development of seafood enterprises in the direction of harmoniously solving the relationship of existing problems within the enterprise such as unstable labor force, pressure on management, product responsibility, pressure to solve problems, etc. environment and still face many challenges on external factors such as lack of customers, market, lack of stakeholder needs in business cooperation, government support policies and pressure on social issues. in business is an issue that businesses need to pay attention to for sustainable development. Sustainable business development is a wide-ranging topic, especially businesses that come in many forms, not only in terms of size, sector and size space, but also in how a business is managed and regulated. operation, legal status, and operational goals. All businesses are part of society, shaped and shaped by the communities in which they operate.

The objective of this paper is to assess the impact of environmental regulations, ecosystem innovation strategies and corporate social responsibility activities on the sustainable development of Vietnamese enterprises in the aquatic industry. produce. The layout of the article in addition to the introduction includes: Literature review, research methods, research results and conclusions.

\section{Literature review}

\subsection{Sustainable Development}

The concept of sustainable development emerged in the 1970s when the world struggled to cope with threats such as rapid population growth and the depletion of natural resources. However, for the first time, the concept of "sustainable development" was clearly defined by the World Council on Environment and Development (WCED) of the United Nations in the report "Our Common Future" in 1987. Sustainable development is defined as: "Development that meets the needs of the present without compromising the ability of future generations to meet their own needs". The 2030 Agenda for Sustainable Development of the United Nations defines Sustainable Development as a close and harmonious combination of three basic elements, namely: Economic development; Social Security; Environmental Protection. These factors are interconnected and are all very important for the well-being of everyone and society as a whole. Every country, every locality, every business, every citizen needs to be positively aware and take specific actions towards sustainable development. The issue of sustainable development is a school of thought - interacting with the relationship between people, social and natural institutions that can be found in the history of development. The concept of sustainable development was widely popularized in 1987 thanks to the Brundtland Report of the World Commission on Environment and Development - WCED (now the Brundtland Commission). This report defines: Sustainable development is "Development that meets the needs of the present without compromising the ability of future generations to meet their own needs". In other words, sustainable development must ensure effective economic development, a just society, and a protected and preserved environment. To achieve this, all socio-economic sectors, authorities, social organizations, businesses, etc. must join hands to implement in order to harmonize 3 main areas: business economic social - environment.

Valentin and Spangenberg (2000); The principles of sustainable development are structured around four themes (economic, social, environmental, and institutional) and six thematic links (for each connection dimension). But the concept of McWilliams \& Siegel (2001) focuses only on one aspect of rare resources and their ability to lead to competitive advantage. As sustainable development can constitute a precious, rare (creative), and difficult to imitate resource or ability to lead to competitive advantage. And Becker (2005) gives three common characteristics (resilience, self-sufficiency and cooperation) of sustainable development. 
Sustainable development in the economic field in Vietnam and its socio-political impacts. Mentioning four issues are: (1) Sustainable development is an urgent requirement and an inevitable trend of the world; Vietnam in the process of integration and development has been actively responding to this trend; (2) Some outstanding achievements in sustainable development in the economic field of Vietnam over the past 20 years of renovation; (3) Some basic socio-political impacts from the achievements of sustainable development in the economic field of Vietnam; (4) Vietnam's economy still has some unsustainable manifestations, but we can overcome it and firmly believe in the future if we have the right and dynamic development solutions. A sustainable development model is proposed, which is only sustainable when it ensures economic growth, equity and social progress, and the environment is protected at the same time. Economic growth, satisfying justice and social progress, but environmental degradation, depletion, will not achieve sustainable development. Economic growth, environmental protection, but society divided between rich and poor, stratified in terms of education, excessive cultural enjoyment, and development will also not be able to have stability for development. A just society, the results of achievements are shared equally for everyone, the environment is protected but the economy does not grow, the model will survive but will not last, especially in a world of decisive competition and more and more exchanges. Sustainable development is an urgent need and an inevitable trend in the development process of human society. Therefore, it has been agreed by countries around the world to build into an Agenda for each historical development period. In general, sustainable development from the above concepts is only mentioned at the macro level, usually on the general scale of the country and mainly refers to the three pillars of economy, society, and environment. To develop sustainably in terms of economy, maintain macroeconomic stability, and ensure economic security. Accelerating economic restructuring and growth model transformation, considering quality, productivity, efficiency, and competitiveness as a top priority, focusing on in-depth development and development of the knowledge economy. Economic growth must be harmoniously combined with cultural development, realize social progress and justice, and constantly improve the people's quality of life. Socio-economic development must always attach importance to environmental protection and improvement, proactively responding to climate change. Our country has conditions for rapid development and the requirements for rapid development are also very urgent. Sustainable development is the basis for fast development, fast development to create resources for sustainable development.

From the concept of sustainable development at the macro level and the business in accordance with the principles of sustainable development, we aim to understand the concept of sustainable development at the micro level of the business. Enterprises are increasingly making a very significant contribution to the sustainable development of society and over the past decades efforts to achieve sustainable development can be seen even on the micro level of businesses, once businesses have decided on a more sustainable development direction than pure profit, business refers to business performance not only in terms of services, products produced and profits, but also in terms of effects on human and social dimensions.

\subsection{Sustainable business development}

Business Development is intended to assist organizations in dealing with uncertain environments, both internally and externally, often with efforts to respond to changing plans to an uncertain environment. Enterprise development efforts, whether supported by an external expert or a professional organization and conducted on an ongoing basis, bring about planned change in organizations and groups within the enterprise. However, they are just one type of change that occurs in organizations, for change can be both planned and unplanned and can occur in all dimensions of the business environment. Andrews (2003) argues that sustainability is not just a matter of philanthropy, altruism, and ethical responsibility, but a core strategic interest. and opportunities for their businesses. Andrews further expands on the concept "A sustainable business is one that adds value to shareholders by contributing more than the competition and becomes the criteria for a sustainable business. Contributing to sustainable development from economic components, supply and improvement". Corporate sustainability is a system around which individual stakeholders are related and operate within a broader socio-ecological system. Individuals, businesses, and socio-ecological systems have existence and purpose needs. Sustainable businesses organize their activities so that both types of needs are simultaneously met for their stakeholders, the business itself and the socio-ecological system. Sustainability is the ability of businesses to thrive in a hyper-competitive and changing global business environment. Businesses that anticipate and manage current and future economic, environmental, and social opportunities and risks by focusing on quality, innovation and productivity will emerge as leaders that have more likely to create a competitive advantage and stakeholder value in the long run.

\subsection{Government environmental regulations and Enterprise sustainable business growth}

Government environmental regulations to achieve the best possible economic outcomes, related to sustainable development. Sustainable development of enterprises not only opens opportunities for business enterprises, but also needs support from enjoying state policies for businesses. According to Le The Gioi et al. (2010) institutional sustainability: related to maintaining appropriate financial, administrative, and organizational capacity in the long term is considered a prerequisite for the success of the three sustainability components (bio-sustainability) Ecological, Economic Sustainability, Social Sustainability). Institutional sustainability encompasses a wide range of regulatory regulations and the institutions to implement them: authorities that govern formally at the governmental, community or informal level. Government regulation is one of the important external factors affecting corporate sustainability, such as regulation such as controlling current environmental behavior, and encouraging business to look at innovations in terms of ecology in the future. 
As such, state-supported housing policies can also promote competitiveness, sustainable businesses and job creation through local and regional approaches based on support for specific regions disadvantaged by providing investment incentives in sectors as part of a broader development agenda. These programs are important to nurture the economy, to foster the creation and growth of sustainable businesses. A special approach to nurturing and developing businesses with participatory policy support from central and local governments in the local economic development community.

\section{$\mathbf{H}_{1}$ : Government environmental regulations have a positive impact on Enterprise sustainable business growth.}

\subsection{Government environmental regulations and eco-innovation strategies}

The lack of awareness among entrepreneurs about protecting the natural environment associated with government activities to increase economic benefits and achieve goals such as poverty alleviation will lead to ecological degradation. To date, it has been difficult to reach a win-win solution in terms of poverty alleviation and protection of the natural environment as policy makers have not been able to implement adequate tools and regulations to regulate the benefits of related parties. Jaffe and Palmer (1997) argue that government regulations on the environment will help businesses gain competitive advantages and develop sustainably. Porter and van der Linder (1995) argue that environmental government regulations not only stimulate firms to innovate by promoting sustainable business growth but can also reduce inefficiencies. of resource allocation and promotion of enterprise competitiveness. They argue that environmental regulations force businesses to innovate, which reduces production costs and increases productivity, sales, and profits. Jové-Llopis and Segarra-Blasco (2018) indicate that environmental regulations have the potential to provide energy efficiency through ecological innovation (Jové-Llopis \& Segarra-Blasco, 2018). In addition, market tools such as permits, and taxes may perform more effectively when stimulating cryptocurrencies (Cai \& Li, 2018). Thus, government environmental regulations can create a context where entrepreneurs innovate to protect the natural environment and pursue economically sustainable growth. Given the importance of the environment in the context of agriculture and food, businesses are concerned about the cost of complying with environmental protection regulations. Since the main goal of managers or entrepreneurs is profit maximization (Rabadán et al., 2019), they will only decide to invest in environmentally sustainable practices when the return on investment is guaranteed (Stucki, 2019). To the best of our knowledge, the decision of entrepreneurs to adopt an ecosystem innovation strategy can be primarily explained by the increasing exposure of businesses to environmental government regulations. more stringent. Second, an ecosystem innovation strategy is a source of competitive advantage (Hojnik \& Ruzzier, 2016) characterized by product differentiation. In this respect, differentiation is an opportunity to increase revenue and environmental performance in response to stakeholder needs. Third, eco-innovation can improve a firm's reputation (Hojnik et al., 2018) because a good reputation increases demand for a firm's products. Therefore, we propose that government environmental regulations have a positive impact on Eco-innovation strategies. Therefore, the following hypothesis is put forth:

\section{$\mathbf{H}_{2}$ : Government environmental regulations have a positive impact on eco-innovation strategies.}

\subsection{Eco- innovation strategies and Enterprise sustainable business growth}

Today's manufacturing enterprises use a lot of resources for environmental improvement activities. This is extremely important because it allows the business to contribute to the overall environmental treatment process, changing production technology with high productivity and low negative environmental impact. Russo and Fouts (1997) suggest a link between environmental strategy and corporate performance because of environmental innovation complemented by increased organizational capacity for employee engagement and learning. and businesses engaged in pollution prevention rather than pollution control. Fairfield et al. (2011) show that government regulations on the environment guide the sustainable development of businesses. Sustainable development enterprises must address environmental and social factors in business operations, such as reducing energy costs, cutting waste treatment costs, and saving fuel. Although such activities reflect business culture and ethics, government regulations on this matter will help businesses to perform more effectively towards the goal of sustainable development. The application of environmental pollution prevention factors belonging to the group of factors inside enterprises for research and sustainable development of enterprises is consistent with the current situation. Take initiatives to promote environmental responsibility; Encourage development and dissemination of environmentally friendly technologies. From that, we believe that environmental pollution prevention has an impact on the sustainable development of enterprises. Sustainable development and economic growth are not contradictory goals. However, economic growth historically uses natural resources and sustainable development minimizes the use of natural resources. In recent years, the literature has reported an increasing awareness of environmental protection, which is fully related to business strategy (Melander, 2020). Eco-innovation is a new process or product that brings value to consumers and businesses while minimizing harm to the environment (Rennings, 2000). Some authors have defined ecological innovation as an innovation that enhances environmental performance and businesses must pay more attention to the impact of their activities on the natural environment. could be about reducing greenhouse gas emissions and waste generation (Santos et al., 2019). Therefore, ecological innovation not only seeks economic progress, but also solves environmental problems and prevents the degradation of natural resources. Environmental benefits from eco-innovation include reduced emissions, reduced material usage, energy savings, adoption of green inputs and increased recycling (Melander 2018, 2020). Several case studies in different countries, such as Germany, show that ecoinnovative products reduce water consumption, land degradation, waste and noise, as well as improve quality air (Horbach et al., 2012). 
Other studies provide evidence that eco-innovative products are associated with ecological performance, such as reduced pollution, reduced inputs, less waste generation and thus reduced degradation. environment (Pujari et al., 2003). In this respect, businesses seek to change their business models to incorporate green and sustainable practices in order to gain a competitive advantage (Bini \& Bellucci, 2020). According to the research results of previous literature, the relationship between the innovation strategy of the ecosystem and the growth and sustainable development of the enterprise is significant for the following reasons: Firstly, the system innovation strategy Ecology enhances the efficient use of inputs to reduce production costs and waste. Second, eco-innovation strategies help create new ways to turn waste into a marketable product to increase profits (Porter \& Van der Linde 1995). Third, the ecosystem innovation strategy helps the business to improve its reputation compared to competitors, which attracts new customers (Melander, 2020) and according to the resource-based theory, the innovation strategy ecosystem will create market advantages leading to sustainable business growth. Several authors have shown a positive relationship between eco-innovation and firm performance (Tseng et al., 2013). In addition, the increase in sales was mainly due to the focus on producing environmentally friendly products (Ar 2012; Saudi et al., 2019). In this regard, enterprises can improve resource productivity through ecological innovation activities to offset environmental costs (Tariq et al., 2019). Therefore, we propose the following hypothesis:

$\mathbf{H}_{3}$ : Eco-innovation strategies have a positive impact on Enterprise sustainable business growth.

2.6. The mediating role of eco-innovation strategies in the relationship between government environmental regulations and Enterprise sustainable business growth

Porter and Van Der Linde (1995) argue that strict government regulations on the environment can drive eco-innovative firms. Because, when the Government's regulations on the environment are too strict, businesses have to think about how to do it effectively, thereby stimulating the strategy of ecosystem innovation. For example, when an enterprise decides to invest in environmental protection solutions, it will offset the amount of money that must be paid for administrative fines if these regulations are not implemented, which leads to mutual benefits as well as helps the enterprises to improve the environment. firms improve their competitiveness (Porter \& Van der Linde, 1995). Furthermore, some authors have emphasized that the Government's strict regulations on the business environment can handle inefficient production stagnation such as saving costs or stimulating ecological innovations (Ramanathan et al., 2017). When implementing an eco-innovation strategy that helps businesses save more money as the process is created through energy conservation and pollution prevention, several studies have supported the fact that government regulations on the environment promote an ecosystem innovation strategy (Rubashkina et al., 2015; Xing et al., 2019). Other studies have demonstrated that Government environmental regulations incentivize businesses to adopt an ecosystem innovation strategy, and this will offset compliance costs, increase product value and firm performance, improve the productivity and competitiveness of enterprises and lead to better environmental quality (Rubashkina et al., 2015). Therefore, we propose the hypothesis:

$\mathbf{H}_{4}$ : Eco-innovation strategies mediate the relationship between Government environmental regulations and Enterprise sustainable business growth.

Furthermore, there are many reasons for businesses to be motivated to adopt ecological innovations.

First, ecological innovation is associated with compliance with environmental regulations to achieve sustainable business growth (Tang et al., 2018).

Second, eco-innovation focuses on entrepreneurs' preferences for how they behave in an environmentally friendly manner to show that they take their responsibility for environmental issues seriously (Dangelico, 2015).

Third, it is based on businesses' responses to environmentally responsible or 'green' awareness, altruism and customer loyalty towards sustainable products and services (Panda et al., 2020).

Eco-innovation thus becomes an essential driver of business activity to alleviate environmental problems and realize sustainable growth. Eco-innovation is an attractive way to promote sustainability by developing processes, methods and products (Ma \& Hu, 2018) while helping businesses create new and enhanced market opportunities competitive advantage (Sarkar 2013). Government regulations on the environment help businesses create an incentive to innovate the ecosystem and thereby help businesses grow and develop sustainably.

\subsection{Corporate social responsibility and sustainable growth and development of enterprises}

The reality in the world has shown that businesses that perform their social responsibility well, their benefits not only do not decrease but also increase. The benefits that businesses get when implementing social responsibility include reduced costs, increased revenue, increased brand value, reduced employee turnover, increased productivity and more opportunities to access new markets. Here are a few examples of the benefits of corporate social responsibility.

First, implementing social responsibility contributes to reducing costs and increasing productivity. An enterprise can save production costs by investing and installing new equipment. For example, a large Polish packaging manufacturer saved US\$12 million over five years through the installation of new equipment, resulting in a $7 \%$ reduction in water use, $70 \%$ wastewater and $87 \%$ gas emissions (Phan et al., 2020). 
Production costs and labor productivity are closely dependent on the human resource management system. An effective human resource management system also helps businesses cut costs and increase labor productivity significantly. Reasonable salary, bonus, clean and safe working environment, training opportunities, and health and education insurance scheme all contribute to reducing employee leave and dropout rates, thus reducing costs. recruitment and training costs for new employees. All of that contributes to reducing production costs and increasing labor productivity.

Second, implementing social responsibility contributes to increased revenue. Every business is located in a certain area. Thus, investing in supporting local economic development can create a better source of labor, a cheaper and more reliable source of supply, and thereby increase revenue. For example, Hindustan Lever Company, a subsidiary of Unilever in India, in the early 1970 s was operating at only 50\% capacity due to a lack of local cow's milk supply and as a result, suffered serious losses. To solve this problem, the company has set up a master program to help farmers increase cow milk production. The program includes training farmers on how to raise livestock, improving basic infrastructure and setting up a committee to coordinate local suppliers. As a result, the number of villages supplying cow's milk has increased from 6 to more than 400, helping the company operate at full capacity and become one of the most profitable business branches of the group (Phan et al., 2020a).

Third, implementing social responsibility contributes to improving the brand value and reputation of the company. Social responsibility can help businesses increase brand value and reputation significantly. In turn, reputation helps businesses increase revenue, attract partners, investors and employees. Around the world, giant companies are spending huge amounts of money to become the ideal business model. For example, consumer electronics company Best Buy has a product recycling program; the famous coffee company Starbucks has been embarking on community activities; Famous French mineral water company Evian distributes its products in eco-friendly water bottles. Multinational corporations such as The Body Shop (British group specializing in the production of skin and hair care products) and IKEA (Swedish furniture trading group) are typical examples. Both companies are well known not only for their quality products and reasonable prices, but also as environmentally and socially responsible businesses (Phan et al., 2020b).

Fourth, implementing social responsibility contributes to attracting a good labor force. A good, capable workforce is a decisive factor in the productivity and quality of the enterprise's products. It is a fact that, in developing countries, there are not many trained human resources of high quality. The problem for businesses is how to attract and retain them and promote their full capabilities in the management, production and business activities of the enterprise. Therefore, attracting and retaining qualified employees is a big challenge for businesses. Under the conditions of the market economy, businesses that pay fair and reasonable wages, provide employees with training opportunities, have health insurance and a clean working environment are likely to attract and retain high quality human resources.

Being aware of the importance and benefits of implementing social responsibility in the context of globalization and international integration, several large Vietnamese enterprises, in addition to paying taxes to the state, have registered sign social responsibility in the form of commitments to society in protecting the environment, with the local community where the business is located and with employees. Therefore, we propose the hypothesis:

\section{H5: Corporate social responsibility has a positive impact on Enterprise sustainable business growth}

2.8. Moderate role of corporate social responsibility in the relationship between government environmental regulations and Enterprise sustainable business growth

A survey by VCCI on the impact of COVID-19 with nearly 10,200 enterprises (nearly 5\% are in the domestic private sector, the rest are FDI) said that $87.2 \%$ of the answers are: strongly or completely negatively affected. Only $11 \%$ said they were not affected and $2 \%$ reported positive. The general economic difficulty means that it is necessary to streamline the apparatus, cut the spending budget, and focus on digital goals for businesses to "survive" through the pandemic. However, in contrast to the above situation, there is an "underground" excitement taking place among Vietnamese businesses that are willing to invest the budget to implement social responsibility. However, it must be admitted that, in recent times in Vietnam, many businesses have not seriously implemented their social responsibility. That is reflected in acts of fraud in business, financial reporting, failure to ensure labor safety, production and trading of poor-quality goods, intentional pollution of the environment. Typically, the discharge of untreated wastewater causing serious environmental pollution to rivers and residential communities of Miwon Company, Hao Duong Tannery Company, Viet Tri Paper Company, Hyundai Company Vinashin (Khanh Hoa), the production of food containing substances harmful to human health, such as soy sauce containing carcinogen 3-MCPD, pho with phormol, foods containing borax, milk containing melamine. In addition, many businesses violate the legal regulations on salary, insurance, and occupational safety for employees is no longer a rare phenomenon, which has been causing pressing problems for society. Currently, there are different opinions about the reasons for the failure to implement social responsibility of many enterprises in Vietnam. Some people believe that corporate social responsibility in Vietnam has not been legalized in all businesses. For large enterprises with export markets, due to the requirements of customers, they are forced to perform social responsibilities, while for small and medium enterprises, due to financial difficulties and lack of legal constraints. Therefore, many businesses only understand social responsibility as "charity contributions". Some others believe that the implementation of social responsibility will increase costs for businesses, reduce the initial competitiveness without seeing immediate benefits, so small and medium enterprises do not want to fulfill social responsibility. In short, the implementation of corporate social responsibility in Vietnam is still relatively difficult. Therefore, we propose the hypothesis: 
H6: Corporate social responsibility activities moderate in the relationship between government environment regulations and Enterprise sustainable business growth.

\section{Research Method}

\subsection{Research sample}

Fishery is a key national economic sector: 9-10\% of total export turnover; ranks $5^{\text {th }}$ in export value from Vietnam behind telephone, textiles, electronics, and footwear and contributes 4-5\% of GDP; One of the top 5 seafood export countries of the world with high export rate to the world's top markets such as the US, EU, Japan. Total production in 2020: 8.4 million MT include: Catching: 3.85 million MT; Aquaculture: 4.56 million MT. Export turnover in 2020: US\$8.4 billion; Labor force: more than 4 million. In particular, the processing and seafood export sector brings jobs to about 300,000 workers (VASEP.com). From 1995 - 2020: Vietnamese fisheries output increased strongly, the output increased more than 6 times, from 1.3 million tons in 1995 to 8.4 million tons in 2020, the average annual growth rate of $8 \%$. In which, aquaculture production accounts for $54 \%$, capture made up $46 \%$.

From 1995-2020: Vietnam aquaculture production increased 11 times, the annual average growth rate of $10 \%$, from 415 thousand tons to nearly 4.6 million tons by 2020 .Aquaculture is mainly in the Mekong Delta (accounting for $95 \%$ of total pangasius production and $80 \%$ of shrimp production) (VASEP.com).

To assess the impact of environmental regulations and social responsibility on the sustainable growth and development of seafood enterprises in Vietnam, we conducted a survey to 1000 businesses across the country, by live streaming, emailing, sending by courier with response temp. As a result, after 3 months of data collection, we collected 806 survey questionnaires, reaching the rate of $80.6 \%$. After entering data and removing the survey questionnaires with insufficient information and suspected of having inaccurate elements, the remaining results were 658 valid questionnaires for analysis and testing of the research hypotheses assist.

\subsection{Research model}

The proposed study of this paper is presented in Fig. 1 as follows,

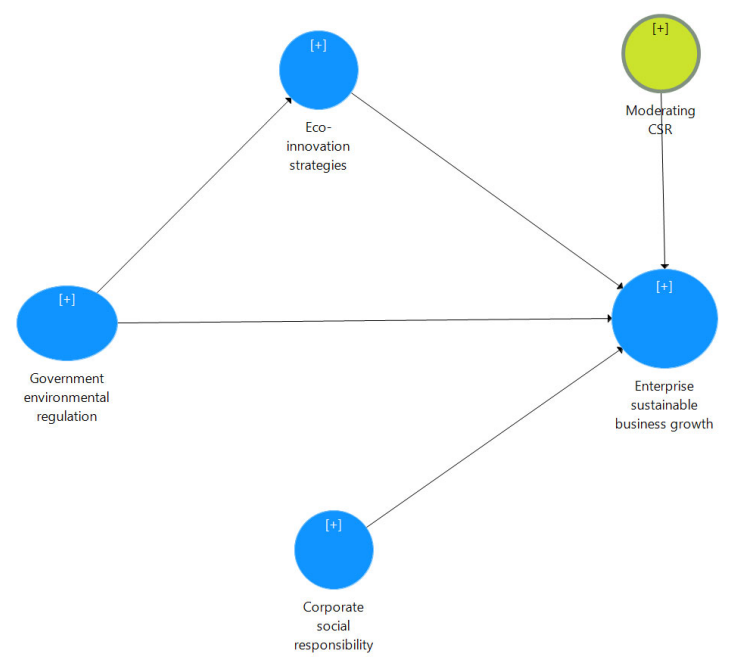

Fig. 1. Research model

Inside:

The sustainable development of the business: To achieve the goal of fast and sustainable development, it is necessary to have a tool to quantify the level of sustainable development of enterprises, which is also the concern of many organizations and businesses. Accordingly, up to now, many sets of criteria for sustainable development of enterprises have been developed. Veleva and Ellenbecker (2001) proposed a set of criteria to measure the sustainable development of enterprises, including 22 criteria in 6 aspects: Use of energy and fuel; Level of emissions to the environment; Economic efficiency; Contributing to community and social development; Workers' rights; Products (designed and manufactured in an environmentally friendly manner). Enterprises, depending on the level of development, can apply these criteria at 5 levels: Level 1 - Showing compliance with regulations; Level 2 - Demonstrates effective application of sustainable development programs; Level 3 - Shows the impact of sustainable development programs on the economy, society and environment; Level 4 - Shows the business's impact on sustainability throughout the supply chain and throughout the product life cycle; Level 5 - Shows the role of enterprises in the overall sustainable development of society. 
Similarly, Krajnc and Glavic (2003) proposed a set of criteria including groups of criteria related to economy, society and environment reflecting aspects such as: Resource consumption; Product; Environment; Economy; Quality; Society of business. In Vietnam in 2016, VCCI developed a set of corporate sustainability indicators (CSI) with 3 economic criteria, 9 environmental criteria and 11 social criteria. Accordingly, every year, VCCI collects information, evaluates, and ranks sustainable businesses. Although the above criteria are different in form, and in some content, they have common points, which are: All evaluate the operation of enterprises based on 3 aspects: economy, society, environment; Besides quantitative indicators such as revenue, salary, working hours, most of the remaining criteria are qualitative; Enterprises can apply part or all these criteria to assess their level of sustainable development.

To measure the growth and sustainable development of Vietnamese seafood enterprises (ESBG), we use 5 items developed and adapted to Vietnam based on research by Amara \& Chen (2020); Phan et al. (2020a). Scales are measured using a 5-point Likert scale ranging from 1 being strongly disagree to 5 being strongly agree.

Government environmental regulation (GER): Measured by 5 items developed from research by Amara \& Chen (2020) and adjusted for Vietnam. Scales are measured using a 5-point Likert scale ranging from 1 being strongly disagree to 5 being strongly agree.

Ecosystem Innovation Strategy (EIS): Measured by 8 items developed from research by Phan et al. (2019); Tran et al. (2020) and Amara and Chen (2020). Scales are measured using a 5-point Likert scale ranging from 1 being strongly disagree to 5 being strongly agree.

Corporate Social Responsibility (CSR): Measured by 15 items developed from research by Le et al. (2019); Phan et al. (2020a, 2020b) and Tran et al. (2020). Scales are measured using a 5-point Likert scale ranging from 1 being strongly disagree to 5 being strongly agree.

\subsection{Analytical techniques}

To analyze the data and test the research hypotheses, we use the software SPSS 23 and Smart PLS 3.6. The process is as follows:

Step 1: We test the reliability of each scale in SPSS23 software

Step 2: Evaluate the measurement model using Smart PLS software with the indicators reported by Hair et al. (2011, 2014, 2017) and Henseler et al. (2009; 2015) suggest the following:

+ Overall reliability

+ Discriminant value

+ Coefficient R - square

+ Coefficient $\mathrm{f}$ - square

+ Model fit

Step 3: Evaluate the structural model

+ Bootstrapping test to test research hypotheses giả

+ Analyze the role of mediating and regulatory variables biến

\section{Result}

The test results on SPSS 23 software show that most of the scales satisfy the condition that the Cronbach Alpha coefficient is greater than 0.7 and the total correlation coefficient is greater than 0.4 . However, there are CSR scales 4.7,13,14 and EIS4 which have total variable correlation coefficient less than 0.3 so we excluded from the research model. The remaining scales were included in the data analysis.

The results of testing the overall reliability of the scales in the latent variables of the research model are as follows:

Table 1

Construct Reliability and Validity

\begin{tabular}{lllll}
\hline & Cronbach's Alpha & rho_A & Composite Reliability & Average Variance Extracted (AVE) \\
\hline Corporate social responsibility & 0.898 & 1.007 & 0.890 & 0.692 \\
Eco-innovation strategies & 0.906 & 0.913 & 0.904 & 0.614 \\
Enterprise sustainable business growth & 0.926 & 0.944 & 0.926 & 0.762 \\
Government environmental regulation & 0.912 & 0.916 & 0.910 & 0.719 \\
\hline
\end{tabular}


From the above research results, all latent variables have Cronbach Alpha coefficients greater than 0.8, which is a very good value (Hair et al., 2011; Henseler et al., 2009). Composite Reliability coefficients are also greater than 0.8 , so the latent variables have good aggregate reliability. The AVE coefficient is also greater than 0.6 to satisfy the analytical condition. The coefficients are modeled as follows:

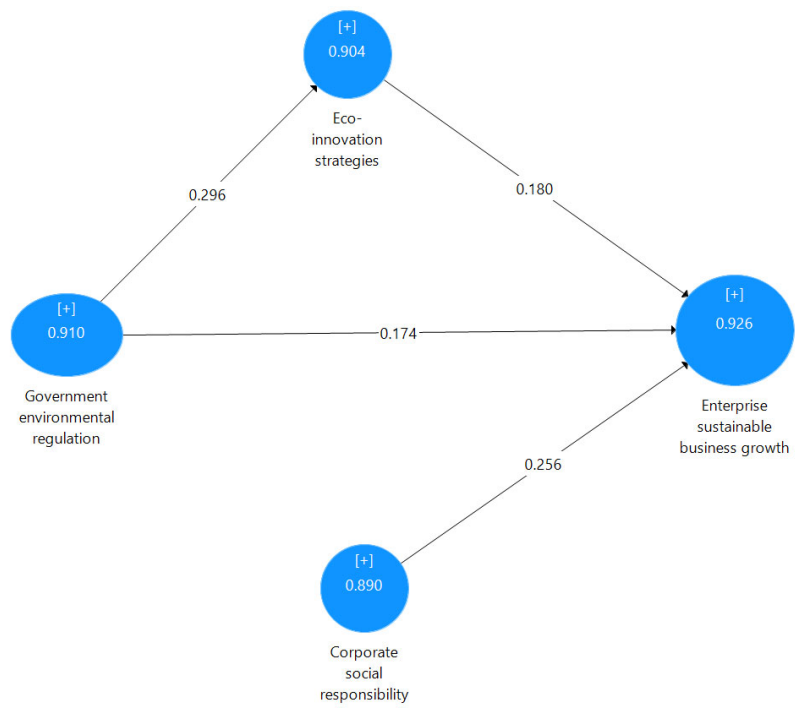

Fig. 2. Composite reliability

The indexes inside the circle are composite reliability indexes that are all greater than 0.8 , showing that the research variables have very good composite reliability (Hair et al., 2011). Next, we test the discriminant validity of the scales in the latent variables as follows:

Table 2

The results of discriminant validity (Fornell-Larcker Criterion)

\begin{tabular}{|c|c|c|c|c|}
\hline & $\begin{array}{l}\text { Corporate social } \\
\text { responsibility }\end{array}$ & $\begin{array}{c}\text { Eco-innovation } \\
\text { strategies }\end{array}$ & $\begin{array}{l}\text { Enterprise sustainable } \\
\text { business growth }\end{array}$ & $\begin{array}{l}\text { Government environ- } \\
\text { mental regulation }\end{array}$ \\
\hline Corporate social responsibility & 0.832 & & & \\
\hline Eco-innovation strategies & 0.397 & 0.784 & & \\
\hline Enterprise sustainable business growth & 0.147 & 0.130 & 0.873 & \\
\hline Government environmental regulation & 0.215 & 0.296 & 0.173 & 0.848 \\
\hline
\end{tabular}

The values on the diagonal are larger than the values outside the diagonal, showing that the research variables satisfy the condition of discriminant validity (Henseler et al., 2015). Next, we evaluate the explanatory level of the research model through the R-square.

Table 3

The results of the R-Square

\begin{tabular}{lll} 
& & R Square Adjusted \\
\hline Eco-innovation strategies & R Square & 0.285 \\
Enterprise sustainable business growth & 0.288 & 0.384 \\
\hline
\end{tabular}

From the above results, it shows that the explanatory level of the variables in the model is quite average. The latent variables in the model explain $39.1 \%$ of the variation of the firm's sustainable growth and development and $28.8 \%$ of the variation of the ecosystem innovation strategy variable. The variables explained quite well the variation of the dependent variables in the research model. The question is how is the association between latent variables through f-square coefficients? The results extracted from the software are as follows:

Table 4

The results of the f Square

\begin{tabular}{|c|c|c|c|c|}
\hline & $\begin{array}{l}\text { Corporate social } \\
\text { responsibility }\end{array}$ & $\begin{array}{l}\text { Eco-innovation } \\
\text { strategies }\end{array}$ & $\begin{array}{c}\text { Enterprise sustainable } \\
\text { business growth }\end{array}$ & $\begin{array}{c}\text { Government environ- } \\
\text { mental regulation }\end{array}$ \\
\hline Corporate social responsibility & & & 0.216 & \\
\hline Eco-innovation strategies & & & 0.303 & \\
\hline \multicolumn{5}{|l|}{ Enterprise sustainable business growth } \\
\hline Government environmental regulation & & 0.312 & 0.359 & \\
\hline
\end{tabular}


The results show that the variables both ensure reliability, discriminant validity and still have a strong association, satisfying the conditions for testing the research hypotheses. The final step in the evaluation of the measurement model is to test the fit of the research model with the research data. The following results:

Table 5

The summary of model fit

\begin{tabular}{lll}
\hline & Saturated Model & Estimated Model \\
\hline SRMR & 0.057 & 0.057 \\
d_ULS & 0.570 & 0.602 \\
d_G & 0.415 & 0.424 \\
Chi-Square & 845.126 & 856.700 \\
NFI & 0.868 & 0.866 \\
\hline
\end{tabular}

The results show that the research data is consistent with the research model.

Finally, we conduct structural model evaluation to test the research hypotheses as follows:

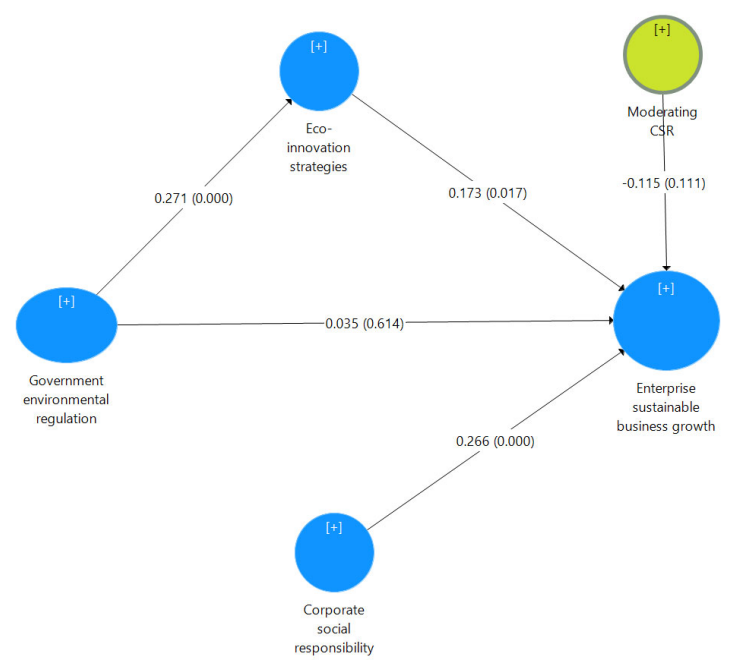

Fig. 3. Bootstrapping results

Research results show that corporate social responsibility has a strong impact at 0.266 at $1 \%$ significance level $\left(\mathrm{P} \_\right.$value $=$ 0.000 ) on the growth and sustainable development of Vietnamese seafood enterprises. The better businesses implement corporate social responsibility, the better the growth and sustainable development of the business. Government regulations on the environment have quite a strong impact on the ecosystem innovation strategy at an impact level of 0.271 at the $1 \%$ significance level $(\mathrm{P}$ value $=0.000)$. This result shows that the Government's regulations on the environment have the effect of encouraging as well as "forcing" Vietnamese seafood enterprises to renew the ecosystem to cut costs, reduce negative impacts on the environment and the community. Ecosystem innovation strategies have a moderate positive impact on the sustainable growth and development of Vietnamese seafood enterprises at an impact level of 0.173 at the 5\% significance level ( $P_{-}$value $=0.017)$. The regulations of the Government and State on the environment have a direct positive impact on the sustainable growth and development of Vietnamese seafood enterprises as follows:

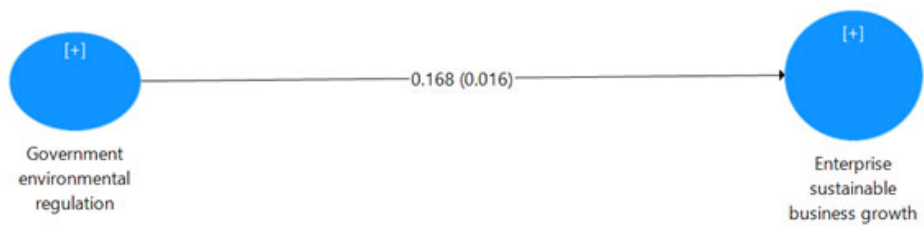

Fig. 4. Direct impact of Government environmental regulation on Enterprise sustainable business growth

From the figure above, Government environmental regulation has a direct positive effect on Enterprise sustainable business growth with an impact factor of 0.168 at the $5 \%$ significance level $\left(\mathrm{P}_{-}\right.$value $\left.=0.016\right)$ As the results in Fig. 3 show in the structural model Overall SEM Government environmental regulation no longer had a statistically significant effect on Enterprise sustainable business growth. This means that the ecosystem innovation strategy is fully mediating in the relationship between Government environmental regulation and Enterprise sustainable business growth. This means that the Government's regulations on the environment must be approved by the strategy of renewing the ecosystem of Vietnamese seafood enterprises 
to improve the efficiency of growth and sustainable development of enterprises. Because currently, Vietnamese seafood enterprises voluntarily implement strategies to renew ecosystems, protect the environment, and build brands, rather than applying regulations in an adversarial manner.

The final hypothesis is that corporate social responsibility has a moderating role in the relationship between Government environmental regulation and Enterprise sustainable business growth. However, according to the test results in Figure 3, it shows that the moderating variable of corporate social responsibility is not statistically significant. Therefore, there is not enough evidence to conclude that corporate social responsibility plays a moderating role in the relationship between Government environmental regulation and Enterprise sustainable business growth.

\section{Conclusion}

For enterprises producing and processing aquatic products for export, it is necessary to focus on investing in the application of advanced science and technology to serve the farming and processing, especially the development of aquatic seed production systems. high quality products, key farming species, high economic value and potential new species. To turn marine aquaculture into a commodity production field, on an industrial scale, creating a large volume of products for processing for export and domestic consumption. To gradually build the seafood processing industry into a spearhead economic sector, large commodity production, and deep processing center. In addition, focusing on building national brands for key seafood products, such as shrimp, tuna, and pangasius, etc. At the same time, closely follow new-generation free trade agreements such as: CPTPP, EVFTA, UKVFTA, RCEP ... combine to promote trade promotion activities, promote images, create leverage to bring Vietnam's seafood exports to the international market.

Proposing the implementation of a sustainable development model in enterprises

To implement sustainable development, businesses first need to consider sustainable development as a strategic goal. On that basis, determine specific criteria and targets for sustainable development, implement and evaluate results. Veleva \& Ellenbecker (2001) propose an 8-step model to implement sustainable development, including:

Determine the long-term goals and vision of the business on sustainable development;

Identify sustainable development criteria in line with reality and business goals;

Selection of criteria to perform within the given time period;

Set specific targets;

Criteria implementation: Including activities such as data collection, calculation, evaluation, and analysis of results;

Monitor and communicate performance with stakeholders;

Implement timely corrective and adjustment actions based on implementation results;

Review criteria, policies, and goals. Set criteria, policies, and goals for the next period.

However, businesses do not necessarily have to choose all the criteria according to the set of criteria to apply, but can start by choosing the essential criteria, feasible, close to the reality of the business. profession to perform. Example: From criteria reflecting regulatory compliance to criteria reflecting sustainability in factories to criteria reflecting sustainability over the product life cycle (Veleva \& Ellenbecker, 2001) ). Businesses can also start by choosing the strategy of "Preventing pollution". After effectively preventing pollution in the factory, enterprises can choose a more influential strategy such as "Product life cycle management", "Clean technology development” (Hart, 1997).

For sustainable development, businesses must aim for a harmonious combination of three economic, social and environmental goals. It is the development of production and business with the goal of maximizing profits but limiting resource consumption, reducing emissions and sharing benefits with stakeholders such as the state, shareholders, employees, etc. customers and communities. This development model helps businesses not only develop the economy but also save resources, protect natural resources and the environment.../.

\section{Acknowledgement}

This research is funded by Vietnam National Foundation for Science and Technology Development (NAFOSTED) under grant number 502.02-2020.26

\section{References}

Amara, D. B., \& Chen, H. (2021). Evidence for the Mediating Effects of Eco-Innovation and the Impact of Driving Factors on Sustainable Business Growth of Agribusiness. Global Journal of Flexible Systems Management, 1-16.

Andrews, D. W. (2003). End-of-sample instability tests. Econometrica, 71(6), 1661-1694. 
Ar, I. M. (2012). The impact of green product innovation on firm performance and competitive capability: the moderating role of managerial environmental concern. Procedia-Social and Behavioral Sciences, 62, 854-864.

Becker, T. E. (2005). Development and validation of a situational judgment test of employee integrity. International Journal of Selection and Assessment, 13(3), 225-232.

Bini, L., \& Bellucci, M. (2020). Business model disclosure in sustainability reporting: two case studies. In Integrated Sustainability Reporting (pp. 117-150). Springer, Cham.

Cai, W., \& Li, G. (2018). The drivers of eco-innovation and its impact on performance: Evidence from China. Journal of Cleaner Production, 176, 110-118.

Cabezas-Rabadán, C., Rodilla, M., Pardo-Pascual, J. E., \& Herrera-Racionero, P. (2019). Assessing users' expectations and perceptions on different beach types and the need for diverse management frameworks along the Western Mediterranean. Land Use Policy, 81, 219-231.

Dangelico, R. M. (2015). Improving firm environmental performance and reputation: The role of employee green teams. Business Strategy and the Environment, 24(8), 735-749.

Fairfield, K., Harmon, J., \& Behson, S. (2011). Implementing sustainability strategies: an integrative model. Organization Management Journal, 8(1), 4-20.

Freeman, R.E. (1984). Strategic Management: A Stakeholder Approach, Boston, MA: Pitman Publishing.

Freeman, I., \& Hasnaoui, A. (2011). The Meaning of Corporate Social Responsibility: The Vision of Four Nations. Journal of Business Ethics, 100(3), 419-443.

Gladwin, T.N. (1993), The global environmental crisis and management education. Environmental Quality Management, 3 , 109-114. https://doi.org/10.1002/tqem.3310030111.

Gooijer, J.D. (2000). Designing a knowledge management performance framework. Journal of Knowledge Management, 4(4), $303-310$.

Hart, S. L. (1997). Beyond greening: strategies for a sustainable world. Harvard Business Review, 75(1), 66-77

Hair, J.F., Ringle, C.M. and Sarstedt, M. (2011). PLS-SEM: in deed a silver bullet, Journal of Marketing Theory and Practice, 19(2), 139-151.

Hair, J.F., Hult, G.T.M., Ringle, C., \& Sarstedt, M. (2013). A Primer on Partial Least Squares Structural Equation Modeling (PLS-SEM), Sage Publications Ltd, London.

Hair, J.F., Henseler, J., Dijkstra, T., Sarstedt, M., Ringle, C., Diamantopoulos, A., Straub, D., Ketchen, D., GTM, H., \& Calantone, R. (2014). Common beliefs and reality about partial least squares: comments on Rönkkö and Evermann, Organizational Research Methods, 17(2), 182-209.

Hair, J. F., Hult, G. T. M., Ringle, C. M., \& Sarstedt, M. (2017). A Primer on Partial Least Squares Structural Equation Modeling (PLS-SEM), 2nd Ed., Sage: Thousand Oaks.

Harrison, J.S., Bosse, D.A. \& Phillips, R.A. (2010), Managing for stakeholders, stakeholder utility functions, and competitive advantage. Strat. Mgmt. J., 31: 58-74. https://doi.org/10.1002/smj.801

Henseler, J., Ringle, C.M., \& Sarstedt, M. (2015). A new criterion for assessing discriminant validity in variance-based structural equation modeling, Journal of the Academy of Marketing Science, 43(1), 115-135.

Henseler, J., Ringle, C.M., \& Sinkovics, R.R. (2009). The use of partial least squares path modeling in international marketing, in Sinkovics, R.R. and Ghauri, P.N. (Eds), New Challenges to International Marketing, Emerald Group Publishing Limited.

Hojnik, J., \& Ruzzier, M. (2016). What drives eco-innovation? A review of an emerging literature. Environmental Innovation and Societal Transitions, 19, 31-41.

Hojnik, J., Ruzzier, M., \& Manolova, T. S. (2018). Internationalization and economic performance: The mediating role of eco-innovation. Journal of Cleaner Production, 171, 1312-1323.

Horbach, J., Rammer, C., \& Rennings, K. (2012). Determinants of eco-innovations by type of environmental impact-The role of regulatory push/pull, technology push and market pull. Ecological Economics, 78, 112-122.

Jaffe, A., \& Palmer, K. (1997). Environmental Regulation and Innovation: A Panel Data Study. The Review of Economics and Statistics, 79(4), 610-619. Retrieved July 15, 2021, from http://www.jstor.org/stable/2951413

Jové-Llopis, E., \& Segarra-Blasco, A. (2018). Eco-innovation strategies: A panel data analysis of Spanish manufacturing firms. Business Strategy and the Environment, 27(8), 1209-1220.

Krajnc, D., \& Glavič, P. (2003). Indicators of sustainable production. Clean Technologies and Environmental Policy, 5(3-4), 279-288.

Le The Gioi, Nguyen Truong Son, \& Nguyen Thi Tram Anh (2010). Building a multi-dimensional analysis framework and index system to evaluate the sustainable development of the fisheries sector - the case of Khanh Hoa seafood industry. Journal of Science and Technology, University of Danang, 5(40). 86-93.

Le, T., Nguyen, T., Phan, T., Tran, M., Phung, X., Tran, T., \& Giao, K. (2019). Impact of corporate social responsibility on supply chain management and financial performance in Vietnamese garment and textile firms. Uncertain Supply Chain Management, 7(4), 679-690.

Santos, D. F. L., Rezende, M. D. V., \& Basso, L. F. C. (2019). Eco-innovation and business performance in emerging and developed economies. Journal of Cleaner Production, 237, 117674.

Ma, L., \& Jiayu, H. (2018) An analysis of the eco-innovation mechanism and policies in the pulp and paper industry based on coupled game theory and system dynamics. Sustainability 10, 3482 
McWilliams, A., \& Siegel, D. (2001). Corporate Social Responsibility: A Theory of the Firm Perspective. The Academy of Management Review, 26(1), 117-127. doi:10.2307/259398

Melander, L. (2018). Customer and supplier collaboration in green product innovation: External and internal capabilities. Business Strategy and the Environment, 27(6), 677-693.

Melander, L. (2020). Success factors for environmentally sustainable product innovation. In Innovation Strategies in Environmental Science (pp. 33-67). Elsevier.

Nguyen, T., Pham, T., Phan, T., Than, T \& Nguyen, T. (2020). Impact of green supply chain practices on financial and nonfinancial performance of Vietnam's tourism enterprises. Uncertain Supply Chain Management, 8(3), 481-494.

Panda, T. K., Kumar, A., Jakhar, S., Luthra, S., Garza-Reyes, J. A., Kazancoglu, I., \& Nayak, S. S. (2020). Social and environmental sustainability model on consumers' altruism, green purchase intention, green brand loyalty and evangelism. Journal of Cleaner production, 243, 118575.

Phan, T., Doan, X., \& Nguyen, T. (2020a). The impact of supply chain practices on performance through supply chain integration in textile and garment industry of Vietnam. Uncertain Supply Chain Management, 8(1), 175-186.

Phan, T. T. H., Tran, H. X., Le, T. T., Nguyen, N., Pervan, S., \& Tran, M. D. (2020b). The Relationship between Sustainable Development Practices and Financial Performance: A Case Study of Textile Firms in Vietnam. Sustainability, 12(15), 5930.

Porter, M., \& Van der Linde, C. (1995). Toward a New Conception of the Environment-Competitiveness Relationship. The Journal of Economic Perspectives, 9(4), 97-118.

Pujari, D., Wright, G., \& Peattie, K. (2003). Green and competitive: Influences on environmental new product development performance. Journal of business Research, 56(8), 657-671.

Ramanathan, R., He, Q., Black, A., Ghobadian, A., \& Gallear, D. (2017). Environmental regulations, innovation and firm performance: A revisit of the Porter hypothesis. Journal of Cleaner Production, 155, 79-92.

Rennings, K. (2000). Redefining innovation-eco-innovation research and the contribution from ecological economics. Ecological Economics, 32(2), 319-332.

Rubashkina, Y., Galeotti, M., \& Verdolini, E. (2015). Environmental regulation and competitiveness: Empirical evidence on the Porter Hypothesis from European manufacturing sectors. Energy Policy, 83, 288-300.

Russo, M. V., \& Fouts, P. A. (1997). A resource-based perspective on corporate environmental performance and profitability. Academy of Management Journal, 40(3), 534-559.

Stucki, T. (2019). Which firms benefit from investments in green energy technologies?-The effect of energy costs. Research Policy, 48(3), 546-555.

Sarkar, A. N. (2013). Promoting eco-innovations to leverage sustainable development of eco-industry and green growth. European Journal of Sustainable Development, 2(1), 171-171.

Saudi, M. H. M., Obsatar Sinaga, G., \& Zainudin, Z. (2019). The effect of green innovation in influencing sustainable performance: Moderating role of managerial environmental concern. International Journal of Supply Chain Management, 8(1), 303.

Tariq, A., Badir, Y., \& Chonglerttham, S. (2019). Green innovation and performance: moderation analyses from Thailand. European Journal of Innovation Management, 22, 446-467

Tang, M., Walsh, G., Lerner, D., Fitza, M. A., \& Li, Q. (2018). Green innovation, managerial concern and firm performance: An empirical study. Business Strategy and the Environment, 27(1), 39-51.

Tseng, M. L., Wang, R., Chiu, A. S., Geng, Y., \& Lin, Y. H. (2013). Improving performance of green innovation practices under uncertainty. Journal of Cleaner Production, 40, 71-82.

United nation (2015), the 2030 Agenda for Sustainable Development, http://www.un.org

Valentin, A., \& Spangenberg, J. (2000). A guide to community sustainability indicators. Environmental Impact Assessment Review, 20, 381-392.

Veleva, V., \& Ellenbecker, M. (2001). Indicators of sustainable production: framework and methodology. Journal of Cleaner Production, 9(6), 519-549

World Commission on Environment and Development (1987). Our Common Future, Oxford University Press.

Xing, X., Liu, T., Wang, J., Shen, L., \& Zhu, Y. (2019). Environmental regulation, environmental commitment, sustainability exploration/exploitation innovation, and firm sustainable development. Sustainability, 11(21), 6001. 
(C) 2021 by the authors; licensee Growing Science, Canada. This is an open access article distributed under the terms and conditions of the Creative Commons Attribution (CC-BY) license (http://creativecommons.org/licenses/by/4.0/). 